\title{
Transmissible Plasmid Factors and Fertility Inhibition in Vibrio cholerae
}

\author{
By K. BHASKARAN AND V. B. SINHA \\ Central Drug Research Institute, Lucknow, India
}

(Accepted for publication I2 August 197I)

\begin{abstract}
SUMMARY
Conjugation in Vibrio cholerae is mediated by a sex factor, designated the $P$ factor. The present report is concerned with the identification of another transmissible factor, labelled the $\mathrm{V}$ factor, in a strain of non-cholera vibrio. Although the $\mathbf{P}$ and $V$ factors are compatible and may coexist in a cell, a phenomenon of repression of $P$ is observed in the presence of the $V$ factor. There is, however, a brief time lag during which $\mathbf{P}^{-} \mathrm{V}^{+}$cells, newly infected with the $\mathbf{P}$ factor, are fertile. The evidence points to the development of a repression mechanism after infection with the $\mathrm{P}$ factor in these strains. Rare recombinants having the $\mathrm{O}$ antigens of the non-cholera vibrio strain (donor) were isolated from a strain of $V$. cholerae (recipient) after conjugation. One such recombinant was $\mathrm{P}^{+} \mathrm{V}-$ and could therefore be used to obtain similar antigenic hybrids from other strains of $V$. cholerae.
\end{abstract}

\section{INTRODUCTION}

An important characteristic of the sex factor $(\mathrm{P})$ in Vibrio cholerae is the correlation between fertility of $\mathrm{P}^{+}$strains and their ability to produce a bacteriocin-like effect on $\mathrm{P}^{-}$ strains (Bhaskaran, 1960, 1964). The latter phenomenon was demonstrated by seeding indicator $\left(\mathrm{P}^{-}\right)$strains in semi-solid agar as in tests for bacteriophages (Adams, 1950) and placing drops of $\mathrm{P}^{+}$cultures at different sites on the lawn after the agar had set. When such a plate was examined after overnight incubation at $37^{\circ}$, the growth of the indicator appeared thinner in these areas, which was presumed to result from the release of lethal or growth-inhibitory substances by the $\mathrm{P}^{+}$cultures. However, this phenomenon could not be reproduced with killed cultures of $\mathrm{P}^{+}$organisms or their filtrates or extracts. On these grounds it might be disputed whether a true bacteriocin was involved in this phenomenon. Alternatively it might be suggested that, under the conditions of the test, autonomous transfer of the $\mathbf{P}$ factor occurred readily from $\mathrm{P}^{+}$to $\mathrm{P}^{-}$cells and an advancing front of newly infected $\mathrm{P}^{+}$cells was established in the medium. If the growth rate of these newly infected cells was different from that of uninfected cells, there could be an apparent thinning effect although no true bacteriocin was involved. Whatever the explanation, this 'spot' test provided an efficient method for differentiating $\mathrm{P}^{+}$from $\mathrm{P}^{-}$strains of $V$. cholerae.

As regards the fertility aspect, it has been shown that the $P$ factor is capable of autonomous transfer from cell to cell by conjugation, at high frequency, between Vibrio cholerae strains (Bhaskaran, Sinha \& Iyer, I967). This, as well as the fact that about $60 \%$ of the cells in $\mathrm{P}^{+}$ cultures showed the presence of sex pili (Bhaskaran, Dyer \& Rogers, I969) was evidence of the derepressed nature of the $\mathbf{P}$ factor. In contrast, chromosomal transfer occurred at low frequencies; the kinetics of this are not known at present.

The present paper gives an account of the identification of another transmissible factor, designated $\mathrm{V}$ factor, in a strain of non-cholera vibrio. This factor (factor $\mathrm{V}$ ) does not appear 
to be capable of mediating chromosomal transfer. If the $\mathbf{P}$ factor is introduced into a cell containing a resident $\mathrm{V}$ factor, repression of the former occurs but only after a lag period during which the $\mathrm{P}$ factor is capable of autonomous transfer as well as chromosomal mobilization. Details of this will be presented and the findings will be discussed with relevance to antigenic variation in vibrios. Certain aspects of this study were reported in brief earlier (Bhaskaran \& Sinha, I97I $a, b$ ).

\section{METHODS}

Bacterial strains. Two strains of Vibrio cholerae and a strain of non-cholera vibrio were used in this study. The distinction between $V$. cholerae and non-cholera vibrios was made according to the classification of Gardner \& Venkatraman (I935), which was based on $O$ antigenic structure. Vibrio cholerae were agglutinated by $\mathrm{O}$ group I (O-I) antiserum and were divisible into two main antigenic subtypes, Inaba (In) and Ogawa $(\mathrm{Og})$. Strains agglutinable by both Inaba and Ogawa type-specific $O$ sera were occasionally encountered and were referred to as the Hikojima subtype. Non-cholera vibrios, on the other hand, were nonagglutinable by $\mathrm{O}-\mathrm{I}$ antiserum and belonged to several other $\mathrm{O}$ groups. Biochemically, cholera and non-cholera vibrios shared several characters (Sen, 1970).

The strains of Vibrio cholerae were v63 (str-s ilv $v^{+}$pur- O-In arg $^{+} l e u^{-} h i s^{+}$) and v $58: \mathrm{SR}$ (str-r ilv- pur $^{+}$O-Og arg $^{-} l e u^{+} h i s^{-}$) which have been described previously (Bhaskaran, I964). Both strains were available as $\mathrm{P}^{+}$and $\mathrm{P}^{-}$sub-lines. The non-cholera vibrio strain was Vizag $136 / 67$, kindly supplied by Professor R. Sen, Serologist to the Government of India, Calcutta. This strain, which will hereafter be referred to as NCVI65, was non-exacting; it was capable of growth on minimal agar.

$O$ antisera. These were prepared by immunizing rabbits as described previously (Bhaskaran \& Sinha, I967). Tube and slide agglutination tests were performed by conventional procedures. In the case of the former, the tubes were incubated at $37^{\circ}$ for $2 \mathrm{~h}$. and then kept overnight in a refrigerator before reading the results. Extinction tests were made when required as described before (Bhaskaran \& Sinha, 1967).

Culture media. Nutrient broth contained (g./l. distilled water): peptone (Oxoid), Io; yeast extract (Oxoid), 2.5; and $\mathrm{NaCl}, 5$; adjusted to $\mathrm{pH} 8.5$ before sterilization. For nutrient agar, nutrient broth was solidified with $\mathrm{I} \%$ agar powder (Oxoid, no. 3). Semi-solid (sloppy) nutrient agar contained $0.4 \%$ agar powder (Oxoid, no. 3 ).

Bacto Brain Heart Infusion (Difco Laboratories, Detroit, Michigan, U.S.A.) was prepared according to directions of the manufacturers by dissolving $37 \mathrm{~g}$. in $1000 \mathrm{ml}$. distilled water, and sterilizing at $15 \mathrm{lb}$./in. ${ }^{2}$ for $10 \mathrm{~min}$.

Minimal medium contained (g./l. distilled water): $\mathrm{K}_{2} \mathrm{HPO}_{4}, 7 ; \mathrm{KH}_{2} \mathrm{PO}_{4}, 3 ; \mathrm{NaCl}, 5$; $\left(\mathrm{NH}_{4}\right)_{2} \mathrm{SO}_{4}, \mathrm{I} ; \mathrm{MgSO}_{4} \cdot 7 \mathrm{H}_{2} \mathrm{O}, 0 \cdot 1$; DL-methionine, O.I. The $\mathrm{pH}$ of the medium was $7 \cdot 2$. Sterile $50 \%$ glucose solution was added to give a final concentration of $0.1 \%$ before use. The medium was solidified, when required, by the addition of I \% agar powder (Oxoid, no. 3 ).

Other supplements-amino acids (valine, leucine, isoleucine, histidine, arginine) and purine (hypoxanthine)-were added to the basal minimal medium, in the manner required, for nutritional tests and for the selective isolation of genetic recombinants. The concentration of these substrates was $0.01 \%(\mathrm{w} / \mathrm{v})$ except in the case of isoleucine when a concentration of $0.002 \%$ (w/v) was used.

Crosses. Overnight nutrient agar slope cultures were suspended in $8 \mathrm{ml}$. Brain Heart Infusion; $0.2 \mathrm{ml}$. of this suspension was inoculated in $10 \mathrm{ml}$. of Brain Heart Infusion contained in I oz. McCartney bottles. These were incubated for $3 \mathrm{~h}$. without agitation in a water bath maintained at $37^{\circ}$. Such cultures, which usually had a viable count of about $10^{9}$ 
organisms/ml., were used for crosses. Requisite volumes of the parent cultures to be crossed were mixed and filtered through membrane filters ('Metricel', Gelman Instrument Co., Ann Arbor, Michigan, U.S.A.; pore size, $0.2 \mu$ ). The membranes, with the organisms embedded on top, were placed on the surface of nutrient agar plates and incubated at $37^{\circ}$ for $60 \mathrm{~min}$. The organisms thus mated were then suspended in fluid minimal medium. For the isolation of recombinants, these suspensions were streaked on appropriate selective minimal agar. For the study of transmissible plasmid factors, the suspensions were diluted and plated on nutrient agar for isolating discrete colonies. In both cases, streptomycin sulphate (I00 $\mu \mathrm{g}$./ $\mathrm{ml}$. in the case of minimal agar, and $500 \mu \mathrm{g} . / \mathrm{ml}$. in the case of nutrient agar) was often included in the medium for selective isolation.

When recombinants were isolated, the precise nutritional requirements were confirmed by subsequent tests, but no attempt was made to determine antigenic subtype (Ogawa or Inaba) in O-I agglutinable colonies.

\section{RESULTS}

Derivation of Vibrio cholerae strains infected with $P$ and/or $V$ factors. With the experience gained already from genetic recombination studies in Vibrio cholerae (Bhaskaran, 1964; Bhaskaran et al. 1967; Bhaskaran, Sinha \& Iyer, 1968), and particularly with the evidence that chromosomal transfer may be mediated by an autonomous sex factor (P factor), it seemed worthwhile to extend the study to non-cholera vibrios as well. This idea received an unexpected stimulus by the observation of a bacteriocin-like effect during routine cross-matching tests, produced by a non-cholera vibrio strain (NCV I65) on an indicator strain of $V$. cholerae ( $\left(\mathrm{V}^{8}: \mathrm{SR} \mathrm{P}^{-}\right)$, used regularly in this laboratory for the identification of $\mathrm{P}^{+}$strains. This was to some extent similar to the effect of $\mathrm{P}^{+}$on $\mathrm{P}^{-}$strains, but nonidentity with the $P$ factor was established by the finding that NCVI65 produced a similar effect on $\mathrm{v} 58: \mathrm{SR}^{+}$, when the latter was used as an indicator.

The newly discovered factor was designated as the $\mathrm{V}$ factor and preliminary experiments confirmed that this factor was transmissible from cell to cell, but not with the same degree of efficiency as observed with the $\mathrm{P}$ factor. Thus, it was possible to have strains $V 58: \mathrm{SR}^{-} \mathrm{P}^{+}$ and $\mathrm{V} 58: \mathrm{SR}^{+} \mathrm{V}^{+}$, by performing appropriate crosses $\left(\mathrm{V} 58: \mathrm{SR}^{-} \times \mathrm{NCVI}^{6} 65 \mathrm{~V}^{+}\right.$and $\mathrm{V} 58$ : $\left.\mathrm{SR}^{+} \times \mathrm{NCV}^{+} 65 \mathrm{~V}^{+}\right)$. Likewise, $\mathrm{v} 63 \mathrm{P}^{-} \mathrm{V}^{+}$and $\mathrm{v} 6{ }_{3} \mathrm{P}^{+} \mathrm{V}^{+}$were obtained by correspon ding crosses between $\mathrm{v} 63$ and $\mathrm{v} 58$ :SR strains.

Table I. Identification of $P$ and $V$ factors in Vibrios

\begin{tabular}{|c|c|c|c|c|}
\hline \multirow[b]{2}{*}{ Test strain } & \multicolumn{4}{|c|}{ Effect on indicator strains* } \\
\hline & $\mathrm{V} 58: \mathrm{SR}^{\mathrm{P}^{-} \mathrm{V}^{-}}$ & $\mathrm{V} 58: \mathrm{SR}^{+} \mathrm{P}^{-}$ & V $58: \mathrm{SR}^{-} \mathrm{P}^{-} \mathrm{V}^{+}$ & $\mathrm{V} 58: \mathrm{SR} \mathrm{P}^{+} \mathrm{V}^{+}$ \\
\hline $\mathrm{V} 58: \mathrm{SR}\left(\mathrm{P}^{-} \mathrm{V}^{-}\right)$ & $\ldots$ & - & $一$ & - \\
\hline $\mathrm{V} 58: \mathrm{SR}\left(\mathrm{P}^{-} \mathrm{V}^{+}\right)$ & g.t. & g.t. & - & 一 \\
\hline V $58: S R\left(P^{+} V^{-}\right)$ & g.t. & $\longrightarrow$ & g.t. & 一 \\
\hline V 58:SR $\left(P^{+} V^{+}\right)$ & g.t. & g.t. & g.t. & - \\
\hline
\end{tabular}

How these strains were differentiated by cross-matching tests is shown in Table I. It will be seen that $\mathrm{V} 58: \mathrm{SR}^{-} \mathrm{V}^{+}$was an efficient indicator for $\mathrm{V} 58: \mathrm{SR}^{+} \mathrm{V}^{-}$and vice versa. Both strains were needed for identifying $\mathrm{P}^{+} \mathrm{V}^{+}$strains. The newly developed $\mathrm{P}^{-} \mathrm{V}^{+}$and $\mathrm{P}^{+} \mathrm{V}^{+}$ strains have remained stable for over 6 months, which indicated that $\mathrm{P}$ and $\mathrm{V}$ factors were compatible with each other, with no evidence of exclusion or superinfection immunity.

In the cross-matching tests outlined in Table I, a technical difficulty was often encountered 
and must be mentioned. The growth of strains containing the $\mathrm{V}$ factor (with or without $P$ factor), was sometimes poor and patchy in semi-solid media; this precluded correct interpretation of the cross-matching tests. Under such circumstances, the test had to be repeated till a uniform growth of the indicator was observed. In contrast, $\mathrm{P}^{+} \mathrm{V}^{-}$and $\mathrm{P}^{-} \mathrm{V}^{-}$strains gave consistently good growths. As such identification of the $\mathrm{V}$ factor was generally easier than the $\mathrm{P}$ factor, when $\mathrm{P}^{-} \mathrm{V}+$ indicator strains had to be used for the latter.

Transfer of $P$ and $V$ factors in Vibrio cholerae by conjugation. With the above mentioned technique available for detecting $\mathrm{P}$ and $\mathrm{V}$ factors in $V$. cholerae, it was possible to assess the frequency of transfer of these factors in crosses. For this purpose, the ratio of mating cells embedded on membrane was kept at $6 \times 10^{9}$ (donor): $4 \times 10^{9}$ (recipient), while the time of incubation was $60 \mathrm{~min}$.

\section{Table 2. Transfer of $P$ and $V$ factors in Vibrio cholerae by conjugation on membrane filter at $37^{\circ}$ for $60 \mathrm{~min}$.}

\begin{tabular}{|c|c|c|c|c|c|c|c|}
\hline \multirow{3}{*}{$\begin{array}{c}\text { Serial } \\
\text { no. }\end{array}$} & \multirow[b]{3}{*}{ Donor } & \multirow[b]{3}{*}{ Recipient } & \multirow{2}{*}{\multicolumn{2}{|c|}{ Initial cell implant }} & \multicolumn{3}{|c|}{ Transfer of } \\
\hline & & & & & & & $P$ and $V$ \\
\hline & & & Donor & Recipient & $P$ factor & $V$ factor & factor \\
\hline I & $v 63 \mathrm{P}^{+} \mathrm{V}^{-}$ & $v_{58}: \mathrm{SR} \mathrm{P}^{-} \mathrm{V}^{-}$ & $6 \times 10^{9}$ & $4 \times 10^{9}$ & I $8 / 20(90)$ & - & - \\
\hline 2 & v $63 \mathrm{P}^{+} \mathrm{V}^{-}$ & V $58: \mathrm{SR} \mathrm{P}^{-} \mathrm{V}^{+}$ & $6 \times 10^{9}$ & $4 \times 10^{9}$ & I $5 / 20(75)$ & - & - \\
\hline 3 & v $63 \mathrm{P}^{-} \mathrm{V}^{+}$ & V $58: S R P^{-} V^{-}$ & $6 \times 10^{9}$ & $4 \times 10^{9}$ & - & $7 / 20(35)$ & 一 \\
\hline 4 & v $63 \mathrm{P}^{-} \mathrm{V}^{+}$ & $\vee 58: S R P^{+} V^{-}$ & $6 \times 10^{9}$ & $4 \times 10^{8}$ & 一 & $5 / 20(25)$ & 一 \\
\hline $\begin{array}{l}4 \\
5\end{array}$ & $\mathrm{v} 63 \mathrm{P}^{+} \mathrm{V}^{+}$ & V $58: S R P^{-} V^{-}$ & $6 \times 10^{9}$ & $4 \times 10^{9}$ & $0 / 20(0)$ & $2 / 20(10)$ & $0 / 20(0)$ \\
\hline $\begin{array}{l}3 \\
6\end{array}$ & $\mathrm{v} 63 \mathrm{P}^{+} \mathrm{V}^{+}$ & V $58: \mathrm{SR}^{+} \mathrm{P}^{-}$ & $6 \times 10^{9}$ & $4 \times 10^{9}$ & 一 & I/20(5) & - \\
\hline 7 & $\mathrm{v} 63 \mathrm{P}^{+} \mathrm{V}^{+}$ & $\mathrm{V} 58: \mathrm{SR} \mathrm{P}^{-} \mathrm{V}^{+}$ & $6 \times 10^{9}$ & $4 \times 10^{9}$ & $3 / 20$ (I 5$)$ & - & - \\
\hline
\end{tabular}

Numerator $=$ no. colonies with the transferred factor $(s)$; denominator $=$ no. colonies tested; figures in parentheses indicate percentage.

From the results, shown in Table 2 , it will be seen that $\mathrm{P}$ transfer from $\mathrm{P}^{+} \mathrm{V}^{-}$to $\mathrm{P}^{-} \mathrm{V}^{-}$ (and $\mathrm{P}^{-} \mathrm{V}^{+}$) cells occurred at high frequency ( 75 to $90 \%$, lines $\mathrm{I}$ and 2 ). The $\mathrm{V}$ factor was also capable of autonomous transfer, though at a frequency less than that observed for the $P$ factor ( 25 to $35 \%$, lines 3 and 4 ). In crosses involving donor strains containing both $P$ and $\mathrm{V}$ factors (lines 5 to 7 ), $\mathrm{P}$ transfer was virtually abolished in one and considerably decreased in the other, while a degree of curtailment in the transfer of $\mathrm{V}$ factor was also observed. This showed immediately that the transmissibility of $\mathrm{P}$, though normally derepressed, was subject to repression by the concurrent presence of the $\mathrm{V}$ factor in the cell. However, the transfer of $\mathrm{P}$ from $\mathrm{P}^{+} \mathrm{V}^{+}$strain occurred to a small extent when the recipient carried the $\mathrm{V}$ factor (line 7 ) and, as will be seen later, this was reflected in the frequency of recombinants as well.

While electron-microscopic studies made in the past showed the presence of sex pili in about $60 \%$ of the cells of $\mathrm{P}^{+}$cultures (Bhaskaran et al. 1969 ), such studies were not possible now to determine whether any pili were produced by the $\mathrm{V}$ factor. This may well be the case and it would be of interest to know if the pili, produced by these two transmissible factors in Vibrio cholerae, differed from one another and in what respects. Further, it may be anticipated that $\mathbf{P}$ pili developed poorly in $\mathrm{P}^{+} \mathrm{V}^{+}$strains to account for the poor transfer of $\mathbf{P}$ factor from these strains, due perhaps to repression by the $\mathrm{V}$ factor.

Crosses between Vibrio cholerae strains carrying $V$ and $P$ factors in various combinations. It was expected that the divergent frequencies of $\mathrm{P}$ and $\mathrm{V}$ transfer, and the phenomenon of repression of $\mathrm{P}$ by association with the $\mathrm{V}$ factor, would be reflected in chromosomal transfer between $V$. cholerae strains in identical crosses. Because of this, it was necessary to ensure that the selective markers used for isolating recombinants could differentiate between normal frequencies of recombination and their reduction to levels so low as to be 
indistinguishable from back mutation rates. Fortunately, in earlier studies with $V$. cholerae strain $\mathrm{I} 62$, a close linkage was observed between pur and $i l v$ regions, and with respect to $\mathrm{O}$, the order is now known to be ...ilv.pur...O... (Bhaskaran, $1964 ;$ and unpublished results). Consequently, in crosses between $s t r-s .$. ilv $^{+}$. pur ${ }^{-} \ldots \mathrm{O} \ldots$ arg $^{+} \ldots$ leu $^{-} \ldots$ his $^{+}$(donor) and $s t r-r . . . i l v^{-} . p u r^{+} \ldots \mathrm{O} \ldots \mathrm{arg}^{-} \ldots \mathrm{leu}^{+} \ldots h \mathrm{~s}^{-}$(recipient) strains, when selection was based on $i l v^{+}$(donor) and str-r (recipient) markers, a good proportion of the recombinants would show linked segregation of $i v^{+}$and pur- from donor to recipient. In actual experience, this is seen in $50 \%$ of the recombinants isolated. Therefore, the occurrence of such colonies bearing linked markers, only one of which is selected, is sure evidence of recombination even if the colonies are few in numbers.

Table 3. Crosses between Vibrio cholerae strains, carrying $P$ and $V$ factors in various combinations

$$
\begin{aligned}
& \text { v63 :str-s ilv }{ }^{+} \text {pur- O-In } \text { arg }^{+} \text {leu- his }{ }^{+} \\
& \text {V 58:SR:str-r ilv } v^{-} \text {pur }{ }^{+} \text {O-Og } \text { arg }^{-} \text {leu }^{+} \text {his }^{-}
\end{aligned}
$$

\begin{tabular}{|c|c|c|c|c|c|c|}
\hline \multirow[b]{3}{*}{ Serial no. } & \multirow{2}{*}{\multicolumn{2}{|c|}{ Cross }} & \multirow{3}{*}{$\begin{array}{l}\text { No. colonies on } \\
\text { pur-arg-his-str } \\
\text { minimal agar/ } \\
2 \times 10^{8} \text { cells } \\
\text { of donor* }\end{array}$} & \multicolumn{3}{|c|}{ Analysis of recombinants } \\
\hline & & & & \multicolumn{2}{|c|}{ Donor marker(s) } & \multirow{2}{*}{$\begin{array}{c}\text { Total } \\
\text { no. } \\
\text { examined }\end{array}$} \\
\hline & $\begin{array}{l}\text { Donor } \\
\text { v63 }\end{array}$ & $\begin{array}{l}\text { Recipient } \\
\text { V 58:SR }\end{array}$ & & $i l v^{+}$ & $i l v^{+}$ & \\
\hline I & $\mathbf{P}^{+} \mathbf{V}^{-}$ & $\mathrm{P}^{-} \mathbf{V}^{-}$ & $120,7 \mathrm{I}$ & 26 & 24 & 50 \\
\hline 2 & $\mathrm{P}^{+} \mathrm{V}^{-}$ & $\mathbf{P}^{-} \mathbf{V}^{+}$ & $\mathrm{I} 24, \mathrm{I} 43$ & 26 & 24 & 50 \\
\hline 3 & $\mathrm{P}^{+} \mathrm{V}^{-}$ & $\mathbf{P}^{+} \mathbf{V}^{-}$ & Nil, nil & - & - & 一 \\
\hline 4 & $\mathbf{P}^{+} \mathbf{V}^{-}$ & $\mathbf{P}^{+} \mathbf{V}^{+}$ & 10,15 & 7 & I3 & 20 \\
\hline 5 & $\mathrm{P}^{-} \mathrm{V}^{+}$ & $P^{-} V^{-}$ & Nil, nil & 二 & - & - \\
\hline 6 & $\mathbf{P}^{-} \mathbf{V}^{+}$ & $\mathbf{P}^{+} \mathbf{V}^{-}$ & Nil, nil & - & - & - \\
\hline 7 & $P^{-} V^{+}$ & $\mathbf{P}^{-} \mathbf{V}^{+}$ & Nil, nil & - & 一 & 一 \\
\hline 8 & $\mathrm{P}^{-} \mathrm{V}^{+}$ & $\mathbf{P}^{+} \mathbf{V}^{+}$ & $\mathbf{I}, \mathbf{I}$ & 2 & Nil & 2 \\
\hline \multirow[t]{2}{*}{9} & $\mathbf{P}^{+} \mathbf{V}^{+}$ & $\mathrm{P}-\mathrm{V}^{-}$ & (Expt. I) nil, nil & 一 & - & - \\
\hline & & & (Expt. 2) nil, 2 & I & I & 2 \\
\hline 10 & $\mathbf{P}^{+} \mathbf{V}^{+}$ & $\mathrm{P}^{+} \mathrm{V}^{-}$ & Nil, nil & - & 一 & - \\
\hline \multirow[t]{2}{*}{ II } & $\mathbf{P}^{+} \mathbf{V}^{+}$ & $\mathrm{P}^{-} \mathrm{V}^{+}$ & (Expt. I) 6, 12 & 6 & I 2 & 18 \\
\hline & & & (Expt. 2) I I, 3 & 7 & 7 & I 4 \\
\hline 12 & $\mathbf{P}^{+} \mathbf{V}^{+}$ & $\mathbf{P}^{+} \mathbf{V}^{+}$ & 2 , nil & 2 & Nil & 2 \\
\hline 13 & $\mathbf{P}^{-} \mathrm{V}^{-}$ & $P^{-} V^{-}$ & I, I & 2 & Nil & 2 \\
\hline
\end{tabular}

These crosses were made between $2 \times 10^{9}$ cells of donor and $8 \times 10^{9}$ cells of recipient on membranes for $60 \mathrm{~min}$. The results are presented in Table 3. As expected, $\mathrm{P}^{+} \times \mathrm{P}^{-}$crosses (lines I and 2) showed a normal frequency of recombination, which has consistently been of the order of I per $2 \times 10^{6}$ donor cells in such crosses. Linkage of the unselected marker (pur ${ }^{-}$) was seen in about $50 \%$ of recombinants. $\mathrm{V}$ factor by itself appeared incapable of mediating chromosomal transfer (lines 5 to 8 ). $\mathrm{P}^{+} \mathrm{V}^{+}$strains showed considerably decreased fertility or none at all (lines 9 to $\mathrm{I} 2$ ) as was expected on account of repression of $P$. A certain degree of fertility was observed in crosses $\mathrm{P}^{+} \mathrm{V}^{-}$(donor) $\times \mathrm{P}^{+} \mathrm{V}^{+}$(recipient) and $\mathrm{P}^{+} \mathrm{V}^{+}$ (donor) $\times \mathrm{P}^{-} \mathrm{V}^{+}$(recipient) (lines 4 and I $\mathrm{I}$ ) which indicated that the presence of the $\mathrm{V}$ factor in the recipient probably improved its recipient efficiency. As already referred to, transfer of $\mathrm{P}$ occurred to a small extent in $\mathrm{P}^{+} \mathrm{V}^{+} \times \mathrm{P}^{-} \mathrm{V}^{+}$matings (line 7 , Table 2).

Crosses between non-cholera vibrio strain, $\mathrm{NCV} 165$, and Vibrio cholerae, $\mathrm{V} 58: \mathrm{SR}$. The recognition of the $\mathrm{V}$ factor in wild-type non-cholera vibrio NCV ${ }^{6} 65$ indicated that this strain (infected with the $\mathrm{P}$ factor or otherwise) would be a poor choice for crosses with $V$. cholerae 
strains, even assuming that there was no incompatibility such as lack of genetic homology, restriction of DNA, etc., between the mated cells. There was, however, the possibility that strain NCV 165 could be made an effective donor if its $V$ factor was lost or removed. Such a strain could then be infected with the $P$ factor which, in its usual derepressed state, may be able to bring about its own transfer as well as that of chromosomal segments. Alternatively, procedures had to be worked out for derepressing the $\mathrm{P}$ factor when it was repressed in $\mathbf{P}^{+} \mathrm{V}^{+}$cells. As very little is known about curing plasmid factors in vibrios, the latter alternative seemed worthy of pursuit.

As a preliminary to this, it was necessary to determine how soon after infection the $\mathbf{P}$ factor was repressed in a cell such as NCV 165 carrying the V factor. If, as in the case of known repressed factors (coll, for example), there was a period of derepression following transfer to a new cell, matings could be done in this phase for the isolation of recombinants. These experiments were therefore done in two stages based on techniques described for coll-mediated genetic transfer in Salmonella typhimurium (Stocker, Smith \& Ozeki, I963). In the first stage, NCV I $65\left(\mathrm{P}^{-} \mathrm{V}^{+}\right)$was crossed with V $58: \mathrm{SR}\left(\mathrm{P}^{+} \mathrm{V}^{-}\right)$for $60 \mathrm{~min}$. on membranes, at the end of which $70 \%$ to $80 \%$ of the former were known to acquire the P factor. The cells suspended from the membrane now contained a good proportion ( 35 to $40 \%$ ) of NCV I65 $\left(\mathrm{P}^{+} \mathrm{V}^{+}\right)$cells, in which the $\mathrm{P}$ factor was acquired recently. Such a suspension was crossed, in stage 2, with the recipient strain, $v_{5} 8: \mathrm{SR}^{-} \mathrm{V}^{-}$, on membrane for $60 \mathrm{~min}$. At the end of this period, the cells were suspended in fluid minimal medium and streaked on selective minimal agar for the isolation of recombinants. These stages are shown in lines 3 and 4 , Table $4 \mathrm{~A}$.

Table 4A. Crosses between non-cholera vibrio strain NCV 165 (str-s ilv ${ }^{+}$O-I 65 arg $^{+}$his $^{+}$) and Vibrio cholerae strain $\mathrm{V} 58: \mathrm{SR}$ (str-r ilv- $\mathrm{O}_{-}{\mathrm{I} \mathrm{arg}^{-}}^{-} \mathrm{his}^{-}$)

Cross

(Contact on membrane filter for 60 min. at $37^{\circ}$ ) No. colonies $/ 5 \times 10^{8}$ cells of $v 58:$ SR strain

\begin{tabular}{|c|c|c|c|c|c|}
\hline Serial No. & Donor $=5 \times 10^{9}$ cells & $\underset{\text { cells }}{\text { Recipient }}=5 \times 10^{9}$ & $* i l v^{+} / s t r-r$ & $\arg ^{+} / s t r-r$ & $h i s^{+} / s t r-r$ \\
\hline I & $\mathrm{NCV} I 65 \mathrm{P}^{-} \mathrm{V}^{+}$ & $\mathrm{V} 58: \mathrm{SR}^{-} \mathrm{P}^{-}$ & I, nil & $\mathrm{I}, 2$ & Nil, nil \\
\hline 2 & $\mathrm{NCV} I 65 \mathrm{P}^{+} \mathrm{V}^{+}$ & $\mathrm{V}_{5} 8: \mathrm{SR}^{-} \mathrm{V}^{-}$ & Nil, nil & $\mathrm{I}, \mathrm{I}$ & Nil, nil \\
\hline 3 & V 58:SR $\mathrm{P}^{+} \mathrm{V}^{-}$ & $\mathrm{NCV}$ I $65 \mathrm{P}^{-} \mathrm{V}^{+}$ & Nil, nil & I, nil & Nil, nil \\
\hline 4 & $\begin{array}{r}\text { Cell suspension } \\
\text { from cross } 3\end{array}$ & $\mathrm{~V}_{5} 8: \mathrm{sRP}^{-} \mathrm{V}^{-}$ & 6,7 & I3, I I & 5,5 \\
\hline 5 & $\mathrm{NCV} 165 \mathrm{P}^{+} \mathrm{V}^{+}$ & V $58: \mathrm{SR} \mathrm{P}^{+} \mathrm{V}^{-}$ & $\mathrm{I}$, nil & 1,2 & $\mathrm{I}, \mathrm{I}$ \\
\hline
\end{tabular}

It will be seen that a low frequency of recombination occurred under these conditions in contrast to negative results with established $\mathrm{P}^{+} \mathrm{V}^{+}$cell lines of NCV I65 (line 2, Table $4 \mathrm{~A}$ ). Other crosses shown in the Table (line I, 3,5) were controls. However, in the absence of closely linked markers in the donor strain, NCV 165 , for scrutiny in the presumptive recombinants, there was no way of confirming that genetic recombination did occur at a low frequency. The only recourse available was to repeat the cross a few times to get a reasonable number of colonies so that they might be screened for the infrequent segregation of unselected markers in the recombinants.

The results of such detailed studies are shown in Table $4 \mathrm{~B}$. The segregation of O-I 65 antigenic marker, in 3 out of 242 colonies tested, may be taken as evidence that the majority of colonies isolated were in fact recombinants. The linkage of this unselected marker with $i l v^{+}$indicated that the $\mathrm{O}$ regions in NCV 165 and $v 58:$ SR were allelic. This finding confirmed 
that the $\mathbf{P}$ factor remained derepressed for a time after transfer to NCV I65 $\left(\mathrm{P}^{-} \mathrm{V}^{+}\right)$strain. The period of derepression was probably brief, as unrestricted multiplication of the cells between the two stages of the experiment (between cross 3 and cross 4 , Table $4 \mathrm{~A}$ ), for a period of 90 min., rendered the cross sterile.

An interesting feature of this study was the manner of segregation of $\mathrm{P}$ and $\mathrm{V}$ factors in the recombinants. The analysis shown in Table ${ }_{4} \mathrm{~B}$ revealed that $\mathrm{P}$ and $\mathrm{V}$ factors segregated separately or were lost independently from the recombinants after joint transfer by conjugation. However, V was eliminated more frequently $(39 \%)$ than P (I I \%) in the recombinants. In similar crosses carried out subsequently, but not recorded in Table $4 \mathrm{~B}$, both the factors ( $\mathrm{P}$ and $\mathrm{V}$ ) were found missing in a few proven recombinants (inheriting $i l v^{+} \ldots \mathrm{O}-\mathrm{I} 65$ region). This was an extraordinary finding. These rare recombinants (devoid of $\mathbf{P}$ and $\mathrm{V}$ factors) as well as others with one of the two factors missing, can, however, be infected with the appropriate factors subsequently, which showed that there was no immune mechanism as may be expected from chromosomal integration of the factor.

Table 4 B. Analysis of recombinants isolated from cross 4 , Table $4 \mathrm{~A}$ (data pooled from three independent crosses)

\begin{tabular}{|c|c|c|c|c|c|c|}
\hline \multirow[b]{2}{*}{ Recombinants } & \multirow[b]{2}{*}{$\begin{array}{c}\text { No. } \\
\text { isolated }\end{array}$} & \multicolumn{5}{|c|}{ Segregation of $\mathrm{P}$ and $\mathrm{V}$ factors } \\
\hline & & $\mathrm{P}^{+} \mathrm{V}^{+}$ & $\mathrm{P}^{+} \mathrm{V}^{-}$ & $\mathbf{P}^{-} \mathrm{V}^{+}$ & $\mathrm{P}^{-} \mathrm{V}^{-}$ & $\begin{array}{l}\text { Total no. } \\
\text { of colonies } \\
\text { tested }\end{array}$ \\
\hline$(s t r-r) i l v^{-}$O-I $\left(\arg ^{+}\right) h_{i s}^{-}$ & 144 & 9 & 2 & 5 & nil & 16 \\
\hline$(s t r-r) i l v^{-}$O-1 $\arg ^{-}\left(h i s^{+}\right)$ & 63 & 1 & 15 & I & nil & 17 \\
\hline$(s t r-r)\left(i l v^{+}\right)$O-I arg $^{-} h i s^{-}$ & 32 & I 5 & 3 & nil & nil & 18 \\
\hline$(s t r-r)\left(\right.$ ilv $\left.^{+}\right)$O-I65 arg $^{-} h^{-} s^{-}$ & 3 & 2 & I & nil & nil & 3 \\
\hline
\end{tabular}

It is tempting to speculate - whatever be the nature of chromosomal transfer - that there was an initial trend at mutual exclusion of $\mathbf{P}$ and $\mathbf{V}$ factors when both were introduced at about the same time in a recipient cell. There was no way of determining whether this occurred also in the absence of chromosomal transfer because of obvious difficulties in experimental design. However, as already seen, a resident factor ( $\mathrm{P}$ or $\mathrm{V}$ ) does not exclude the other in $\mathrm{P}^{+} \mathrm{V}^{-} \times \mathrm{P}^{-} \mathrm{V}^{+}$and $\mathrm{P}^{-} \mathrm{V}^{+} \times \mathrm{P}^{+} \mathrm{V}^{-}$crosses (Table 2 ). One may visualize two maintenance sites in the cell for $\mathrm{P}$ and $\mathrm{V}$ factors which can be occupied only sequentially but not simultaneously. The lag thus introduced may result in the elimination of one or (rarely) both factors during cell division.

There was no clue how the $\mathbf{P}$ factor, which was normally derepressed in a cell, could get repressed in the presence of another transmissible factor like V. If the restriction was akin to $\mathrm{fi}^{+}$effect of one plasmid on another (Egawa \& Hirota, 1962; Watanabe \& Fukasawa, 1962) one had to assume that the $\mathrm{V}$ factor coded for a repressor specific for $\mathrm{P}$. In such an event it would be expected that the P factor would be repressed immediately on entry into a cell containing the $\mathrm{V}$ factor. This was not the case, as a brief period of derepression and donor competence preceded repression and sterility. It appeared more likely that the presumptive repressor was synthesized after the entry of the $\mathrm{P}$ factor and not before. This could mean either complementation between $\mathrm{P}$ and $\mathrm{V}$ factors in the biosynthesis of the repressor or the inducibility of the $\mathrm{V}$ factor for repressor synthesis. 


\section{DISCUSSION}

Experimental evidence presented in this paper shows how the interactions between two transmissible factors ( $\mathrm{P}$ and $\mathrm{V}$ ) present in vibrio cells were studied. In the absence of evidence for their alternative maintenance at chromosomal sites, as stipulated for episomes (Jacob \& Wollman, I958) these entities are best regarded as plasmids (Lederberg, 1952). The main point of interest in this study was the demonstration that, when $P$ factor was introduced into a cell containing the $V$ factor, the former was repressed after a brief lag period. During this lag, the $\mathrm{P}$ factor was capable of self transfer as well as chromosomal mobilization. The alternative situation, namely introduction of $\mathrm{V}$ into a $\mathrm{P}^{+}$cell, could not be studied because of a lesser efficiency of $\mathrm{V}$ transfer, which should leave behind a good proportion of $\mathrm{P}^{+}$cells (uninfected with the $\mathrm{V}$ factor) and which would continue to exercise fertility in crosses.

Another feature of this study was the identification of a shift of a chromosomal region, coding for $\mathrm{O}$ antigenic specificity, from a non-cholera vibrio ( $\mathrm{NCV} \mathrm{I} 65$ ) to a strain of Vibrio cholerae. This was recognized because of a chromosomal sequence in the recipient which was ...ilv.pur...O . . arg..., the first two showing close linkage. The fortuitous isolation of a $\mathrm{P}+\mathrm{V}^{-}$recombinant of this kind from such a cross (Table $4 \mathrm{~B}$ ) enabled further recombination studies between $V$. cholerae strains $\vee 58$ and $v 63$, in which the $\mathrm{O}-\mathrm{I} 65$ region could be shunted back and forth. Thus several O-I65 hybrids are now available, resistant and sensitive to streptomycin.

Further extension of this antigenic variation to other wild Vibrio cholerae strains is possible, provided streptomycin-resistant mutants are used. In such crosses, as illustrated by str-s $\mathrm{O}-\mathrm{I} 65 \mathrm{P}^{+} \times$str-r O-I $\mathrm{P}^{-}(\mathrm{V}$. cholerae $), \mathrm{O}-\mathrm{I} 65$ hybrids of the latter could be selectively isolated on the basis of the sensitivity of the donor strain to streptomycin and the sensitivity of the recipient $V$. cholerae (including biotype $\mathrm{El}$ Tor) to high titre preparations of group IV phage (Mukerjee, I963). By such techniques, O-I 65 hybrids have in fact been isolated from three strains of $V$. cholerae, belonging to types I, 3 and 5 of Feeley (1965). As discussed elsewhere, such hybrid strains should prove to be of value in immunological studies (Bhaskaran \& Sinha, I97I $b$ ).

It may be recalled that different gene clusters, designated as $r f a, r f b, r f c$, etc., have been mapped in Salmonella strains which are concerned with the assembly of core and side chains of polysaccharide determinants (Makela \& Stocker, 1969). Such precise studies are yet to be made with vibrio species and one may expect that other as yet unidentified regions in the chromosome of vibrio strains may specifically influence the development of $\mathrm{O}$ antigens.

Dr K. Bhaskaran is grateful to the World Health Organization for providing financial support to this study. He is also thankful to Professor G. G. Meynell (Lister Institute of Preventive Medicine, London) for his comments on the manuscript. This paper is Communication no. I660 of the Central Drug Research Institute.

\section{REFERENCES}

Adams, M. H. (1950). Methods of study of bacterial viruses. In Methods in Medical Research, vol. 2 , pp. I-73. Edited by J. H. Comroe, Jun. Chicago: The Year Book Publishers.

BHASKARAN, K. (1960). Recombination of characters between mutant stocks of Vibrio cholerae, strain I62. Journal of General Microbiology 23, 47-54.

BHASKARAN, K. (1964). Segregation of genetic factors during recombination in Vibrio cholerae, strain I62. Bulletin of the World Health Organisation 30, 845-853.

Bhaskaran, K., Dyer, P. Y. \& Rogers, G. E. (1969). Sex pili in Vibrio cholerae. Australian Journal of Experimental Biology and Medical Science 47, 647-650. 
Bhaskaran, K. \& Sinha, V. B. (I97 I a). Hybridization in Vibrios. Indian Journal of Experimental Biology 9 , I 19-I 20.

Bhaskaran, K. \& Sinha, V. B. (I97I $b$ ). Evaluation of antibacterial and antitoxic immunity in cholera. Current Science 40, 28I-284.

Bhaskaran, K. \& Sinha, V. B. (1967). Attenuation of virulence in Vibrio cholerae. Journal of Hygiene, Cambridge 65, $135-148$.

Bhaskaran, K., Sinha, V. B. \& Iyer, S. S. (1967). Conjugation of Vibrio cholerae strains on membrane filters. Current Science 36, 257-258.

Bhaskaran, K., Sinha, V. B. \& IYer, S. S. (1968). Antigenic variation in Vibrio cholerae resulting from chromosomal transfer by conjugation. Current Science 37, 488-489.

Egawa, R. \& Hirota, Y. (1962). Inhibition of fertility by multiple drug-resistance factor (R) in Escherichia coli K-I 2. Japanese Journal of Genetics 37, 66-69.

Feeley, J. C. (1965). Classification of Vibrio cholerae (Vibrio comma), including El Tor vibrios, by infrasubspecific characteristics. Journal of Bacteriology 89, 665-670.

Gardner, A. D. \& Venkatraman, K. V. (I935). The antigens of the cholera group of vibrios. Journal of Hygiene, Cambridge 35, 262-282.

J $\mathrm{ACOB}$, F. \& Wollman, E. L. (1958). Les episomes, éléments génétiques ajoutés. Comptes Rendus des Séances de l'Academie de Sciences 247, I54-156.

Lederberg, J. (1952). Cell genetics and hereditory symbiosis. Physiological Reviews 32, 403-430.

Makela, P. H. \& Stocker, B. A. D. (1969). Genetics of polysaccharide biosynthesis. Annual Review of Genetics 3, 29I-322.

MukERJEe, S. (1963). The bacteriophage susceptibility test in differentiating Vibrio cholerae and Vibrio el tor. Bulletin of the World Health Organization 28, 333-336.

SEN, R. (1970). A comparison of strains of so-called NAG vibrios with those of strains of Vibrio cholerae. Indian Journal of Medical Research 58, 1528-1535.

Stocker, B. A. D., Sмith, S. M. \& Ozeki, H. (1963). High infectivity of Salmonella typhimurium newly infected by the col I factor. Journal of General Microbiology 30, $201-221$.

Watanabe, T. \& Fukasawa, T. (I962). Episome mediated transfer of drug resistance in Enterobacteriaceae. IV. Interactions between resistance transfer factor and F-factor in Escherichia coli K-12. Journal of Bacteriology 83, 727-735. 